\title{
Perceived roles and function of school psychologists by college of education students
}

\author{
Akor Isaiah Akem ${ }^{1}$, Victor Tavershima Ukeli ${ }^{2, *}$ \\ ${ }^{1}$ Department of Curriculum Studies, College of Education, Katsina-Ala, Nigeria \\ ${ }^{2}$ Department of Educational Psychology, College of Education, Katsina-Ala, Nigeria \\ *E-mail address: fevichalix@yahoo.com
}

\begin{abstract}
The purpose of this study was to examine College of Education students' perceptions of school psychologist's roles and functions. Participants were 200 (164) students in College of Education, Katsina-Ala. A questionnaire was employed to collect the data. It was found that college students majoring in secondary education rated all roles/functions as significantly more important than those majoring in primary education $(\mathrm{p}<.05)$. Students majoring in secondary education and those majoring in primary education differed significantly in their expectation on who they thought should serve the various roles and functions of a school psychologist if a school psychologist is not available. NCE 2 rated all of the roles/functions significantly higher than did NCE $1(\mathrm{p}<.05)$. However, NCE 1 and NCE 2 did not differ significantly $(p>.01)$ on who they thought should perform the various roles and functions of an unavailable school psychologist. Implications of the findings were also presented in this article.
\end{abstract}

Keywords: education; student; psychology

\section{INTRODUCTION}

School psychologists are highly trained in both psychology and education. School psychologists work collaboratively with teachers, parents, and other related professionals to provide supportive learning environments for the improvement of students in various aspects. Studies of students' perception on roles and functions of school psychologists enable trainers of school psychologists to better understand viewpoints and needs of school psychological services. That is useful for the improvement of training future school psychologists. Research on students' perception of roles and functions of school psychologists is particularly urgent in Benue State because the profession of School Psychology in Benue State is still at the beginning stage. The training of new school psychologists there certainly needs researchbased guidance.

Several studies on the roles and functions of school psychologists as perceived by various groups of people have been conducted. Farrell, Jimerson, Kalambouka, and Benoit (2005) examined teacher's view of school psychologists in eight countries, i.e., Cyprus, Denmark, England, Estonia, Greece, South Africa, Turkey and the United States. It was indicated that in most countries, the teachers would like school psychologists to spend time working with parents, as well as training and advising them on the development of new curriculum materials and less time working with individual children. Watkins, Crosby, and 
Pearson (2001) surveyed the perceptions of school staff on roles of school psychologists. It was found that they gave very high rating to six services, i.e. assessment, special education input, consultation, counseling, intervention, and behavior management. Hagemeier, Bischoff, Jacobs, and Osmon (2008) also studied the role perceptions of the school psychologist by school personnel. It was found that most school staff members regarded consultation with parents and teachers, and intervention as an important role of school psychologists. In addition, Violato, Rattan, Gornall, and Perks (2001) studied the perceptions of the general public on the role of Canadian school psychologists. It was indicated that, overall, respondents had a fairly accurate sense of the roles of school psychologists. Moreover, Poulou (2003) examined the reflections of school psychology students on the role of school psychologists. The result indicated that the majority of students attributed the role of leader to the school psychologist in relation to school personnel. The result also indicated that the school psychologists were expected to work on providing prevention, implementing treatment of children's problems, and facilitating teachers' tasks.

Trice (2007) found that advanced psychology students view assessment as the chief role of school psychologists to the exclusion of other roles; consultation, counseling and research. Farrell, Jimerson, and Oakland (2007) synthesized the studies of school psychology in 43 countries around the world. It was indicated that the core services of school psychologists generally included direct services (e.g., counseling, assessment and assistance with academic work) and indirect services (e.g., consultation with teachers, consultation with parents, implementing interventions). They also indicated that the relative amount of time invested in school psychologists' various services varied considerably between countries. Finally, Jimerson, Graydon, Curtis, and Staskal (2007) surveyed school psychology in 11 countries around the world. It was found that the most preferred role of school psychologists perceived by school psychologists varied from country to country (psycho-educational evaluations, counseling students, providing primary prevention programs and consultation with teachers/staff). However, administrative responsibility was unanimously rated as the least desirable role of school psychologists.

Not only have past research studies investigated what roles and functions school psychologists hold and perform in different countries, past research studies also have determined if these roles and functions change over time. These determinants were examined: (a) school district demands and expectations, (b) districts perception of its needs, (c) community response to service, and (d) desired functions of the school psychologist (Tangdhanakanond \& Archwamety, 2012) Almost 20 years later Swerdlik and French (2000) still predicted that school psychology programs at colleges would continue to change to meet the needs of consumers in the $21^{\text {st }}$ century, and roles and functions of school psychologists must change to meet these needs. Winikur and Daniels (2002) compared percent times devoted to various roles and functions of school psychologists in New Jersey over three school years: 1973-74, 1974-75, and 1977-78. They found no significant change over those three academic years. However, Mooney (2005), in a survey of 154 Nebraskan school administrators, found that their perception of relative importance of various roles and functions of school psychologists changed substantially between the time they first became school administrators and the time they responded to the survey. Statistical analysis showed that as time passed, they looked much more favorably on consultation and intervention roles and functions. Nevertheless, assessment was always ranked first. This emergence of the role of consultation and intervention functions becoming more prominent seems to be an international trend as noted by Wilkinson (2006) who sees a shift internationally of school 
psychology services from emphasis on assessment to consultation, problem solving, and behavioural intervention.

Although numerous studies have been conducted on the perception of roles and functions of school psychologists in many countries, none has been conducted in Benue State. No research study has examined the perceptions of College of Education students on this matter. The profession of School Psychology in Benue State is still at the beginning stage so it would be interesting to find out what Benue State students think of this profession. The purpose of the present study was to investigate College of Education students' perceptions on roles and functions of school psychologists. More specifically, four research questions were asked:

(a) Do primary education majors differ significantly from secondary education majors in rating the importance of the five roles of school psychologists (assessment, counseling students, intervention, consultation with teachers, and consultation with parents)?

(b) Do second-year education majors differ significantly from third-year education majors in rating the importance of those five roles of school psychologists?

(c) Do primary education majors differ significantly from secondary education majors in specifying who should serve the functions of school psychologists in the absence of school psychologists?

(d) Do second-year education majors differ significantly from third-year education majors in specifying who should serve the functions of school psychologists in the absence of school psychologists?

\section{METHODS AND PROCEDURES}

\section{Participants}

The participants of this research were 200 (164) students (120 male and 80 female students) in College of Education, Katsina-Ala. This number of students included 83 NCE 2 and $81 \mathrm{NCE} 1$ whose majors were primary education and secondary education. Multistage random sampling was employed to get the samples of this study. Students were first stratified by their status (NCE 2 and NCE 1). Then, a simple random sampling procedure was used to obtain a sample from each of the NCE 2 and NCE 1 groups.

\section{Instrument}

The survey questionnaire, Survey of College of Education Students on the Profession of School Psychologists, developed by the researchers, was employed in this research. The survey was divided into two parts. In part one, student status, gender, age, and major fields of studies were asked as the respondents' demographic information. In addition, the respondents were asked to rate their familiarity with the profession of school psychology on a seven-point semantic differential scale. In part two, the respondents were asked to specify who should serve the five functions of a school psychologist (assessment, counseling students, intervention, consultation with teachers and consultation with parents) if a school psychologist is not available. Respondents were also asked to rate the importance of each of those functions on a seven-point semantic differential scale. The reliability of this questionnaire was 0.85 as determined by the Cronbach's alpha coefficient.

\section{Procedure}

The questionnaire was randomly distributed to 200 respondents; 100 NCE 2 and 100 NCE 1 of College of Education, Katsina-Ala. The questionnaires were administered to NCE 2 
and NCE 1 respondents whose majors were primary education as well as secondary education in four classes to maximize the return rate. The respondents were allowed to complete the questionnaires in ten minutes before the end of the classes. The 200 questionnaires were returned.

\section{RESULTS}

The ratings on the importance of the various roles and function of a school psychologist by primary education and secondary education students, as well as by NCE 2 and NCE 1 were analyzed using descriptive statistics (means and standard deviations). A two-way analysis of variance (ANOVAR) with repeated measures on one factor was also employed to compare primary education and secondary education students on the perceived importance of the various roles and functions of a school psychologist. The independent factor was group (primary vs. secondary education students), and the repeated-measure factor was role/function of a school psychologist (assessment, counseling students, intervention, consultation with teachers, and consultation with parents). The mean ratings of various roles/functions of school psychologist by primary education students and secondary education students and standard deviations were as shown in Table1 and Figure1.

Table 1. Mean Ratings $(1=$ low, $7=$ high $)$ of Various Roles/Functions of School Psychologist by Primary Education and Secondary Education Students, and Standard Deviations.

\begin{tabular}{|c|c|c|c|c|c|c|c|c|c|c|c|c|}
\hline \multirow[t]{2}{*}{ Majors } & \multicolumn{2}{|c|}{ Assessment } & \multicolumn{2}{|c|}{$\begin{array}{l}\text { Counseling } \\
\text { students }\end{array}$} & \multicolumn{2}{|c|}{ Intervention } & \multicolumn{2}{|c|}{$\begin{array}{l}\text { Consultation } \\
\text { with } \\
\text { teachers }\end{array}$} & \multicolumn{2}{|c|}{$\begin{array}{l}\text { Consultation } \\
\text { with parents }\end{array}$} & \multicolumn{2}{|c|}{ Combined } \\
\hline & $M$ & $S D$ & $M$ & $S D$ & $M$ & $S D$ & $M$ & $S D$ & $M$ & $S D$ & $M$ & $S D$ \\
\hline Pri Ed & 5.21 & 1.43 & 6.34 & 1.23 & 6.11 & 1.19 & 5.80 & 1.41 & 5.95 & 1.32 & 5.88 & 1.37 \\
\hline Sec Ed & 5.65 & 1.05 & 6.60 & 0.73 & 6.46 & 0.94 & 6.11 & 1.04 & 6.32 & 0.86 & 6.23 & 0.99 \\
\hline Combined & 5.44 & 1.27 & 6.47 & 1.02 & 6.29 & 1.09 & 5.96 & 1.24 & 6.14 & 1.13 & & \\
\hline
\end{tabular}

It was found that the overall mean rating of the various roles/functions of school psychologist by secondary education students was statistically significantly higher than the overall mean rating of the various roles/functions of school psychologist by primary education students, $F(1,162)=5.81, p<.05$. It was also found that there were statistically significant difference among the mean ratings of various roles/functions of school psychologist, $F$ (4, $648)=43.97, p<.01$. Students (primary education and secondary education students combined) reported that counseling students was the most important role/function of school psychologist $(M=6.47, S D=1.02)$, followed by intervention $(M=6.29, S D=1.09)$, consultation with parents $(M=6.14, S D=1.13)$, consultation with teachers $(M=5.96, S D=$ $1.24)$, and assessment $(M=5.44, S D=1.27)$, respectively. 


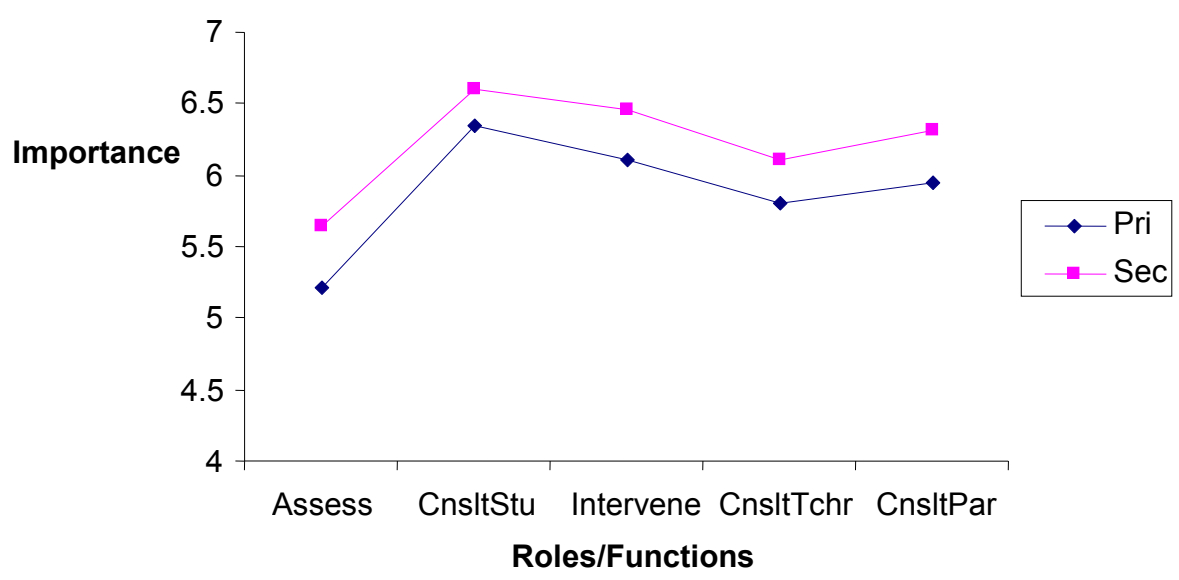

Figure 1. Roles and functions importance rating of primary education students compared with roles and functions importance rating of secondary education.

However, the interaction effect between group (primary vs. secondary education students) and role/function of a school psychologist (assessment, counseling students, intervention, consultation with teachers, and consultation with parents) was not statistically significant, $F(4,648)=0.34, p>.05$ (see Figure 1 for the absence of interaction between the group of students and the role/function of school psychologist).

A two-way analysis of variance with repeated measures on one factor was also performed to compare NCE 2 and NCE 1 on the perceived importance of the various roles and functions of a school psychologist. The independent factor was group (NCE 2 vs. NCE 1), and the repeated-measure factor was role/function of a school psychologist (assessment, counseling students, intervention, consultation with teachers, and consultation with parents).

Table 2. Mean Ratings $(1=$ low, $7=$ high $)$ of Various Roles/Functions of School Psychologist by NCE 2 and NCE 1, Standard Deviations, and Sample Sizes.

\begin{tabular}{lccccccccccccc}
\hline Majors & \multicolumn{1}{c}{ Assessment } & $\begin{array}{c}\text { Counselling } \\
\text { students }\end{array}$ & \multicolumn{1}{c}{ Intervention } & $\begin{array}{c}\text { Consultation } \\
\text { with } \\
\text { teachers }\end{array}$ & $\begin{array}{c}\text { Consultation } \\
\text { with parents }\end{array}$ & Combined \\
& \multicolumn{1}{c}{$M$} & $S D$ & $M$ & $S D$ & $M$ & $S D$ & $M$ & $S D$ & $M$ & $S D$ & $\mathbf{5 . 1}$ & $M$ & $S D$ \\
\hline NCE 2 & 5.31 & 1.30 & 6.21 & 1.14 & 6.16 & 1.04 & 5.80 & 1.28 & 5.93 & 1.21 & 5.88 & 1.24 \\
NCE 1 & 5.57 & 1.23 & 6.74 & 0.78 & 6.43 & 1.12 & 6.12 & 1.18 & 6.36 & 0.99 & 6.24 & 1.14 \\
Combined & 5.44 & 1.27 & 6.47 & 1.02 & 6.29 & 1.09 & 5.96 & 1.24 & 6.14 & 1.13 & & \\
\hline
\end{tabular}




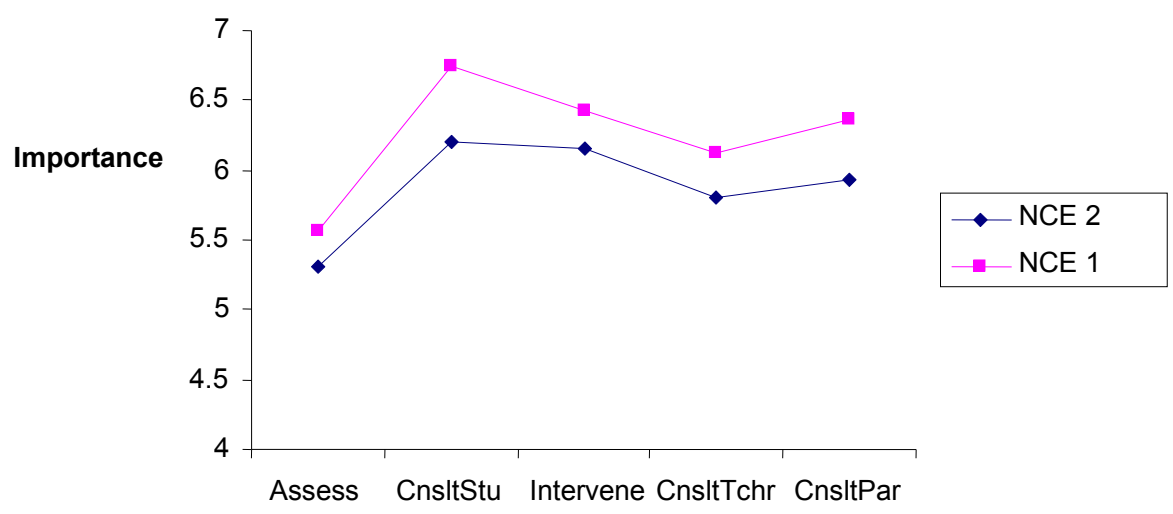

Roles/Functions

Figure 2. Roles and functions importance rating of NCE 2 compared with roles and functions importance rating of NCE 1 .

Table 2 and Figure 2 show the mean ratings of various roles/functions of school psychologist by NCE 2 and NCE 1 and standard deviations. It was found that the overall mean rating of the various roles/functions of school psychologist by NCE 1 was statistically significantly higher than the overall mean rating of the various roles/functions of school psychologist by NCE $2, F(1,162)=6.49, p<.05$.

It was also found that there were statistically significant difference among the mean ratings of various roles/functions of school psychologist, $F(4,648)=44.12, p<.01$. Students (NCE 2 and NCE 1 combined) reported that counseling students was the most important role/function of school psychologist $(M=6.47, S D=1.02)$, followed by intervention $(M=6.29$, $S D=1.09)$, consultation with parents $(M=6.14, S D=1.13)$, consultation with teachers $(M=$ $5.96, S D=1.24)$, and assessment $(M=5.44, S D=1.27)$, respectively.

However, the interaction effect between group (NCE 2 vs. NCE 1) and role/function of a school psychologist (assessment, counseling students, intervention, consultation with teachers, and consultation with parents) was not statistically significant, $F(4,648)=0.97, p$ $>.05$ (see Figure 2 for the absence of interaction between the group of students and the role/function of school psychologist).

The results on who should perform the various roles and functions of a school psychologist in Benue were as shown in Table 3 and Table 4. Note that in Table 3, the percentages of secondary education students specifying school counselor as a person who should perform the assessment activities, counseling students' activities and intervention activities in the absence of a school psychologist were significantly higher than those of primary education students ( $p<.01, p<.05, p<.05$, respectively).

In addition, the percentage of secondary education students specifying other persons who should perform the intervention activities in the absence of a school psychologist was also significantly higher than that of primary education students $(p<.05)$.

It was indicated in the Table 4 that significant differences did not occur $(p>.01)$ between NCE 2 and NCE 1 regarding the opinion of who should perform the various roles and functions of a school psychologist in his/her absence. 
Table 3. Frequency Count and Percentage of Primary Education and Secondary Education Students on the Perceptions of Who Should Perform the Various Roles and Functions of a School Psychologist.

\begin{tabular}{|c|c|c|c|c|c|}
\hline \multirow{2}{*}{$\begin{array}{l}\text { Roles/functions } \\
\text { Person }\end{array}$} & \multicolumn{2}{|c|}{ Primary Education } & \multicolumn{2}{|c|}{ Secondary Education } & \multirow{2}{*}{$\chi^{2}$} \\
\hline & Freq (Total) & $\%$ & Freq (Total) & $\%$ & \\
\hline \multicolumn{6}{|l|}{ Assessment } \\
\hline school principal & $9(80)$ & 11.25 & $8(84)$ & 9.52 & 0.01 \\
\hline teacher & $47(80)$ & 58.75 & $40(84)$ & 47.62 & 1.62 \\
\hline school counsellor & $45(80)$ & 56.25 & $69(84)$ & 82.14 & $11.77 * *$ \\
\hline \multicolumn{6}{|l|}{ Counselling students } \\
\hline school principal & $18(80)$ & 22.50 & $11(84)$ & 13.10 & 1.89 \\
\hline teacher & $69(80)$ & 86.25 & $71(84)$ & 84.52 & .008 \\
\hline school counsellor & $58(80)$ & 72.50 & $73(84)$ & 86.90 & $4.43^{*}$ \\
\hline parents & $67(80)$ & 83.75 & $79(84)$ & 94.05 & 3.46 \\
\hline older sister or brother & $31(80)$ & 38.75 & $42(84)$ & 50.00 & 1.67 \\
\hline monk, priest, or minister & $12(80)$ & 15.00 & $8(84)$ & 9.52 & 0.69 \\
\hline \multicolumn{6}{|l|}{ Intervention } \\
\hline school principal & $23(80)$ & 28.75 & $21(84)$ & 25.00 & 0.13 \\
\hline teacher & $67(80)$ & 83.75 & $77(84)$ & 91.67 & 1.72 \\
\hline school counsellor & $49(80)$ & 61.25 & $65(84)$ & 77.38 & $4.30^{*}$ \\
\hline other students & $37(80)$ & 46.25 & $53(84)$ & 63.10 & $4.04 *$ \\
\hline parents & $65(80)$ & 81.25 & $75(84)$ & 89.29 & 1.52 \\
\hline older sister or brother & $26(80)$ & 32.50 & $34(84)$ & 40.48 & 0.81 \\
\hline \multirow{2}{*}{$\begin{array}{l}\text { Roles/functions } \\
\text { Person }\end{array}$} & \multicolumn{2}{|c|}{ Primary Education } & \multicolumn{2}{|c|}{ Secondary Education } & \multirow{2}{*}{$\chi^{2}$} \\
\hline & Freq (Total) & $\%$ & Freq (Total) & $\%$ & \\
\hline \multicolumn{6}{|l|}{ Consultation with teachers } \\
\hline school principal & $38(80)$ & 47.50 & $50(84)$ & 59.52 & 1.92 \\
\hline Teacher & $25(80)$ & 31.25 & $38(84)$ & 45.24 & 2.82 \\
\hline school counsellor & $50(80)$ & 62.50 & $60(84)$ & 71.43 & 1.10 \\
\hline university educational professor & $33(80)$ & 41.25 & $35(84)$ & 41.67 & 0.00 \\
\hline $\begin{array}{l}\text { official from ministry of } \\
\text { education }\end{array}$ & $18(80)$ & 22.50 & $23(84)$ & 27.38 & 0.29 \\
\hline \multicolumn{6}{|l|}{ Consultation with parents } \\
\hline school principal & $20(80)$ & 25.00 & $20(84)$ & 23.81 & 0.00 \\
\hline teacher & $74(80)$ & 92.50 & $82(84)$ & 97.62 & 1.34 \\
\hline school counsellor & $44(80)$ & 55.00 & $59(84)$ & 70.24 & 3.45 \\
\hline
\end{tabular}

$$
* p<.05, * * p<.01
$$


Table 4. Frequency Count and Percentage of NCE 2 and NCE 1 on the Perceptions of Who Should Perform the Various Roles and Functions of a School Psychologist.

\begin{tabular}{|c|c|c|c|c|c|}
\hline \multirow{2}{*}{$\begin{array}{l}\text { Roles/functions } \\
\text { Person }\end{array}$} & \multicolumn{2}{|c|}{ NCE 2} & \multicolumn{2}{|c|}{ NCE 1} & \multirow{2}{*}{$\chi^{2}$} \\
\hline & Freq (Total) & $\%$ & Freq (Total) & $\%$ & \\
\hline \multicolumn{6}{|l|}{ Assessment } \\
\hline school principal & $8(83)$ & 9.64 & $9(81)$ & 11.11 & 0.00 \\
\hline teacher & $48(83)$ & 57.83 & $39(81)$ & 48.15 & 1.18 \\
\hline school counsellor & $59(83)$ & 71.08 & $55(81)$ & 67.90 & 0.08 \\
\hline \multicolumn{6}{|l|}{ Counselling students } \\
\hline school principal & $14(83)$ & 16.87 & $15(81)$ & 18.52 & 0.01 \\
\hline teacher & $71(83)$ & 85.54 & $69(81)$ & 85.19 & 0.00 \\
\hline school counsellor & $69(83)$ & 83.13 & $62(81)$ & 76.54 & 0.74 \\
\hline parents & $71(83)$ & 85.54 & $75(81)$ & 92.59 & 1.43 \\
\hline older sister or brother & $32(83)$ & 38.55 & $41(81)$ & 50.62 & 1.95 \\
\hline monk, priest, or minister & $7(83)$ & 8.43 & $13(81)$ & 16.05 & 1.57 \\
\hline \multicolumn{6}{|l|}{ Intervention } \\
\hline school principal & $21(83)$ & 25.30 & $23(81)$ & 28.40 & 0.07 \\
\hline teacher & $72(83)$ & 86.75 & $72(81)$ & 88.89 & 0.03 \\
\hline school counsellor & $58(83)$ & 69.88 & $56(81)$ & 69.14 & 0.00 \\
\hline other students & $41(83)$ & 49.40 & $49(81)$ & 60.49 & 1.62 \\
\hline parents & $69(83)$ & 83.13 & $71(81)$ & 87.65 & 0.36 \\
\hline older sister or brother & $28(83)$ & 33.73 & $32(81)$ & 39.51 & 0.37 \\
\hline \multirow{2}{*}{$\begin{array}{l}\text { Roles/functions } \\
\text { Person }\end{array}$} & \multicolumn{2}{|c|}{ NCE 2} & \multicolumn{2}{|c|}{ NCE 1} & \multirow{2}{*}{$\chi^{2}$} \\
\hline & Freq (Total) & $\%$ & Freq (Total) & $\%$ & \\
\hline \multicolumn{6}{|l|}{ Consultation with teachers } \\
\hline School Principal & $42(83)$ & 50.60 & $46(81)$ & 56.79 & 0.41 \\
\hline Teacher & $31(83)$ & 37.35 & $32(81)$ & 39.51 & 0.02 \\
\hline School Counsellor & $59(83)$ & 71.08 & $51(81)$ & 62.96 & 0.88 \\
\hline $\begin{array}{l}\text { University Educational } \\
\text { Professor }\end{array}$ & $31(83)$ & 37.35 & $37(81)$ & 45.68 & 0.85 \\
\hline $\begin{array}{l}\text { Official from Ministry of } \\
\text { Education }\end{array}$ & $22(83)$ & 26.51 & $19(81)$ & 23.46 & 0.73 \\
\hline \multicolumn{6}{|l|}{ Consultation with parents } \\
\hline School Principal & $18(83)$ & 21.69 & $22(81)$ & 27.16 & 0.40 \\
\hline Teacher & $79(83)$ & 95.18 & $77(81)$ & 95.06 & 0.00 \\
\hline School Counsellor & $55(83)$ & 66.27 & $48(81)$ & 59.26 & 0.59 \\
\hline
\end{tabular}

${ }^{*} p<.05,{ }^{* *} p<.01$ 


\section{DISCUSSION}

\section{Students' Perceptions of Importance of the Various Roles and Functions of a School Psychologist}

In this study, secondary education subjects students rated all of the roles/functions significantly higher than their primary education counterparts. This indicted that secondary education students' perceptions of the importance of the various roles/functions of a school psychologist were higher than those of primary education students.

This should not be surprising considering the fact that nowadays in Benue there are guidance teachers who perform the roles/functions of school psychologists in all of the secondary schools whereas there is none serving those roles/functions in the primary schools. Therefore, secondary education students (who need to study services provided to secondary schools) had greater familiarity with the roles/functions of a school psychologist than primary education students. A direct implication of the result from this part of the present study is that educators, especially in Colleges of Education, should try to find ways to make primary education students realize the importance of school psychologists more.

Interestingly, this study found that NCE 2 rated all of the roles/functions significantly higher than NCE 1 did. This may be because NCE 2 are more mature and they study more psychology courses than NCE 1. As a result, they are more exposed to the roles/functions of school psychologists. This implies that Colleges of Education should introduce educational psychology as well as roles and functions of a school psychologist in earlier years of study because psychology is one of the important foundations of teacher education.

Note in Table 1 and Table 2 that students perceived the assessment role as the least important role of school psychologists compared with other roles (i.e., counseling students, intervention, consultation with teachers, and consultation with students). This may be because guidance teachers are not authorized to administer psychological tests. In general, they send students suspected of having learning difficulties to a psychiatrist for diagnosis by psychological tests. For this reason, students may think that assessment is the role of a psychiatrist, not the role of a school psychologist.

This could result in their evaluating the assessment role of a school psychologist as lowest in importance. If this reason is true, a national debate needs to be started on whether psychological testing in schools should be performed by only psychiatrists or should school psychologists be authorized to administer psychological tests as well, especially, to school children.

Although College of Education students rated the assessment role the lowest, it was found that they still rated this role significantly higher than their university counterparts (Archwamety, McFarland, Livinston, \& Tangdhanakanond, 2007; Archwamety, McFarland, \& Tangdhanakanond, 2009). Archwamety et al. (2007, 2009) also found that College of Education students rated the other roles/functions (intervention, consultation with teachers, and consultation with parents) significantly lower than their university counterparts except for the counseling students role/function which was rated equally important by the two groups.

This pattern of lower emphasis on assessment in favor of other roles/functions a school psychologist by university education students is consistent with Tangdhanakanond \& Archwamety's (2012) observation that, in countries where school psychology profession is in place, there has been a shift internationally of school psychology services from assessment emphasis to consultation problem solving and behavioral intervention. 


\section{Students' Perceptions of Who Should Perform School Psychologists' Functions if School Psychologists Are Not Available}

As indicated in Table 3, primary education and secondary education students differed significantly on who should assume the assessment, counseling students and intervention roles in the absence of a school psychologist. Secondary education students expected school counselors to assume the assessment, counseling students, and intervention roles, but they also expected other students to perform the intervention role more than their primary counterparts did. In Benue State, the strategy of buddy assistance has been widely used in secondary schools recently. According to this strategy, high-achievement students are paired with low-achievement students to assist them in learning what they do not understand. This may account for the present study's finding that secondary education students expected other students to perform the intervention role more than their primary education counterparts.

The finding on College of Education students' expectation of school counselors to serve the assessment, counseling students, and intervention roles has implications for the university authorities. Assessment, counseling, and intervention skills should be provided in staff development programs for school counselors. That way, school counselors can work more effectively in helping students improve themselves where the school psychology profession is not available or while it is under the establishment.

\section{CONCLUSION}

The findings of this study provide valuable information and implications for Colleges of Education and university authorities in Benue in order to improve their existing education curriculum and to start a blueprint for training future school psychologists. Firstly, the education curriculum could be revised to have students take an educational psychology course (which should include the roles and functions of a school psychologist) earlier. Secondly, the topic of roles and functions of a school psychologist could be more heavily emphasized in the Primary Education curriculum. Thirdly, curriculum for school counseling and guidance (which produces school counselors and guidance teachers) can incorporate educational and psychological assessment as a major component together with counseling and intervention skills. Staff development programs in these areas for existing school counselors should also be provided. Fourth, the strategy of buddy assistance or related strategies such as peer tutoring should be incorporated into or emphasized in education curriculum; not only in secondary education but in primary education as well. Finally, College of Education and educational authorities in Benue can start drawing a blueprint to produce future school psychologists because education students, as shown in the present study, already have some perception of the role and function of a school psychologist and have some good ideas on who should perform the various functions of school psychologists in their absence. It is time to have real school psychologists in Benue State. 


\section{References}

[1] Archwamety T., McFarland M., Livingston W., Tangdhanakanond K. (2007). American vs. Thai Students on Roles/Functions of School Psychologists. Poster session presented at the National Association of School Psychologists Conference, New York, NY.

[2] Archwamety T., McFarland M., Tangdhanakanond K., School Psychology International 30(3) (2009) 255-264.

[3] Fagan T., Journal for Vocational Special Needs Education 4(3) (2002) 33-36.

[4] Farrell P., Jimerson S. R., Kalambouka A., Benoit J., School Psychology International 26(5) (2005) 525-544.

[5] Farrell P. T., Jimerson S. R., Oakland T. D. (2007). School Psychology Internationally: A synthesis of Findings. In S. R. Jimerson, T. D. Oakland, \& P. T. Farrell. (Eds.), The handbook of International School Psychology (pp. 501-509). Thousand Oaks, CA: Sage Publications.

[6] Hagemeier C., Bischoff L., Jacobs J., Osmon W. (2008). Role Perceptions of the School Psychologist by School Personnel. Paper presented at the Annual National Convention of the National Association of School Psychologists, Orlando, FL, April 1998. (ERIC Document Reproduction Service No. ED 420 023)

[7] Jimerson S. R., Graydon K., Curtis M., Staskal R. (2007). The International School Psychology Survey: Insights from School Psychologists Around the World. In S.R. Jimerson, T. D. Oakland, \& P. T. Farrell. (Eds.), The handbook of International School Psychology (pp. 481-500). Thousand Oaks, CA: Sage Publications.

[8] Poulou, M., School Psychology International 24(4) (2003) 378-393.

[9] Swerdlik M. E., French J. L., School Psychology Review 29(4) (2000) 577-588.

[10] Tangdhanakanond K., Archwamety T., Journal of School Psychology 28(9) (2012) 213-223.

[11] Trice, A. (2007) Psychology Majors' Knowledge of School Psychology. Poster session presented at the National Association of School Psychologists Conference, New York,

[12] Violato C., Rattan G., Gornall M., Perks B., Journal of School Psychology 19(3) (2001) 222-225.

[13] Watkins M. W., Crosby E. G., Pearson J. L., School Psychology International 22(1) (2001) 64-73.

[14] Wilkinson L. A., School Psychology International 27(4) (2006) 426-438.

[15] Winikur D. W., Daniels T., School Psychology Review 11(4) (2002) 438-441.

[16] Andrzej Borowski, International Letters of Social and Humanistic Sciences 1 (2013) 14-18.

[17] Hussein Meihami, Bahram Meihami, International Letters of Social and Humanistic Sciences 7 (2013) 86-95. 